Collection: IUFRO 7.01.00 - Ilhéus (Brazil, 2013) \& Beijing (China, 2014)

"Forest Response to Climate Change and Air Pollution"

Guest Editors: Paoletti E, Kozovitz A, Feng Z, Bytnerowicz A

\title{
Sensitivity of European beech trees to unfavorable environmental factors on the edge and outside of their distribution range in northeastern Europe
}

\author{
Algirdas Augustaitis ${ }^{(1)}$, Almantas \\ Kliučius ${ }^{(1)}$, Vitas Marozas ${ }^{(1)}$, \\ Mantas Pilkauskas ${ }^{(1)}$, Ingrida \\ Augustaitiene $^{(1)}$, Adomas Vitas ${ }^{(2)}$, \\ Tomasz Staszewski ${ }^{(3)}$, Aris \\ Jansons ${ }^{(4)}$, Andrejs Dreimanis ${ }^{(5)}$
}

\begin{abstract}
European beech is a successful tree species outside its distribution range in northeastern Europe, where Prussian foresters introduced it mainly into Scots pine stands. This forest management practice resulted in new issues related to the sensitivity of European beech to current environmental changes in areas outside its natural range. We hypothesized that recent global environmental changes promoted the northeast migration of European beech outside its distribution range in Europe. To test this hypothesis, dendrochronological analysis of beech tree ring series was performed for eight sites located in Poland, $\mathrm{Li}$ thuania and Latvia. Frost in winter months and heat in June, along with drought in the vegetation period, limited beech tree growth outside its natural distribution range in northeast Europe. Higher air concentration of surface ozone and sulphur deposition level reinforced the negative effect of the detected key meteorological variables on beech growth, while higher air concentrations and deposition of nitrate had a positive effect. These factors explained about $50 \%$ of the total variation in increment indexes of beech trees at sites on the northeasren edge of their range. The observed trends of beech growth over the last $\mathbf{2 5}$ years has determined favorable conditions for planting this tree species outside its natural range in northeastern European forests.
\end{abstract}

Keywords: European Beech, Tree Increment Indexes, Meteorological Parameters, Ozone, Acidifying Compounds and Balkan Peninsulas, and from southern England to Ukraine (Teissier du Cros et al. 1981). In central Europe, beech is a component of lowland forests, while in the Mediterranean area it is a typical mountain species (Scalfi et al. 2004). Its proportion in central European forest is currently increasing, particularly where forests with a high percentage of conifers are being converted into more natural mixed forests (Tarp et al. 2000, Cufar et al. 2008). Today, European beech is also a markedly successful species in the northeast of its distribution range
(1) Aleksandras Stulginskis University, Akademia, LT-53362 Kaunas dstr. (Lithuania); (2) Vytautas Magnus University, LT-46324 Kaunas (Lithuania); (3) Institute for Ecology of Industrial Areas, Katowice, Poland; (4) Latvian State Forest Research Institute "Silava" (Latvia); (5) Latvian University of Agriculture (Latvia)

@ Algirdas Augustaitis (iaugustaitiene@gmail.com)

Received: Jul 12, 2014 - Accepted: May 26, 2015

Citation: Augustaitis A, Kliučius A, Marozas V, Pilkauskas M, Augustaitiene I, Vitas A, Staszewski T, Jansons A, Dreimanis A (2015). Sensitivity of European beech trees to unfavorable environmental factors on the edge and outside of their distribution range in northeastern Europe. iForest 9: 259-269. - doi: 10.3832/ifor1398-008 [online 2015-10-16]

Communicated by: Elena Paoletti and its distribution area may be larger than originally assumed (Bolte et al. 2007). Prussian foresters promoted European beech in some areas of Latvia, Lithuania and northeast Poland in the nineteenth century by planting stands near or even outside the range edge (Dreimanis 2004). Past forest management is probably the main cause of the contraction in the postglacial European beech range (Bolte et al. 2007). Due to its higher tolerance to abiotic and biotic threats accompanying climate change and an increased competitive ability compared to boreal tree species, these forest management practices ensure beech migration toward the northeast (Bolte et al. 2010). There, European beech partially overlaps with the boreal coniferous species on loamy moraine soils in pure or mixed stands, usually with Scots pine (Bolte et al. 2007).

European beech is also one of the most thoroughly investigated European tree species, due to its wide distribution range and domination as well as high ecological and economic importance (Dittmar et al. 2003, Jarcuška 2009). Nonetheless, a limited number of studies have examined preor mature beech tree growth on the edge or outside their natural distribution range in relation to meteorological parameters and environmental pollutants in northeast 


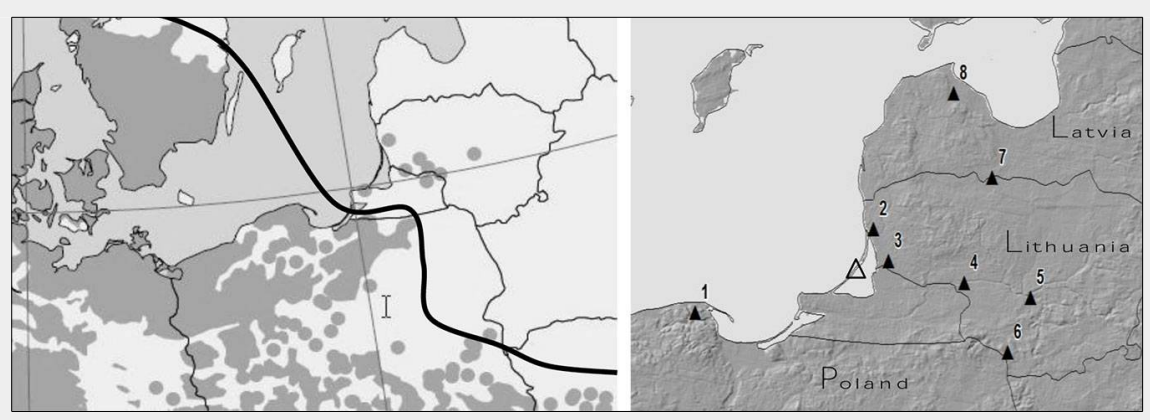

Fig. 1 - (Left panel): beech tree distribution range in northeast Europe (continuous line); (right panel): location of experimental sites (black triangles) and the Preila EMEP station (empty triangle - EUFORGEN 2009).

Europe. The first data on beech growth outside its distribution range were presented by Latvian forest researchers (Dreimanis 2004). In Lithuania such investigations began in 2010 (Augustaitis et al. 2012, Pilkauskas et al. 2011, Marozas et al. 2014). However, with increased mean air temperature and precipitation amount, followed by the increase in vegetative growth period, new issues arose related to the sensitivity and resistance of beech on the edge and out side of its distribution concerning the impact of acidifying compounds and surface ozone (Jump et al. 2006). The importance of this problem increases due to the fact that beech trees growing in the understory of Scots pine increase the productivity of stands by $30-70 \%$ even outside of their natural distribution range (Gradeckas \& Malinauskas 2005).

The present study aimed to determine the sensitivity of beech trees growing on the edge and outside of their distribution range to meteorological conditions and air pollutants, including surface ozone, by employing dendrochronological studies for different regions going from south to north and from west - the Baltic seaside to east. The objectives were:

(i) to detect differences in beech tree growth on the edge of their distribution range and outside it in northeast Europe;

(ii) to detect key meteorological parameters and environmental pollutants which could have resulted in the significant differences in beech tree growth at the study sites;

Tab. 1 - Topography and main characteristics of the monitored beech stands on the edge and outside of their distribution range. Altitudes of the sites were obtained from the elevation map of Europe (European Environment Agency 2014).

\begin{tabular}{|c|c|c|c|c|c|c|c|c|c|c|}
\hline \multirow{2}{*}{$\begin{array}{l}\text { Site } \\
\text { No }\end{array}$} & \multirow{2}{*}{ Location } & \multirow{2}{*}{ Country } & \multicolumn{2}{|c|}{$\begin{array}{l}\text { Coordinates } \\
\text { WGS }\end{array}$} & \multicolumn{2}{|c|}{$\begin{array}{l}\text { Coordinates } \\
\text { Lambert }\end{array}$} & \multirow{2}{*}{$\begin{array}{c}\text { Altit. } \\
\mathrm{m}\end{array}$} & \multirow{2}{*}{$\begin{array}{l}D_{1.3} \\
c m\end{array}$} & \multirow{2}{*}{$\begin{array}{c}\mathrm{H}, \\
\mathrm{m}\end{array}$} & \multirow{2}{*}{$\begin{array}{c}\text { Sample } \\
\text { trees } \\
\text { unit }\end{array}$} \\
\hline & & & Lat & Long & Lat & Long & & & & \\
\hline 1 & Kartuzy & $\mathrm{PL}$ & 54.72 & 18.17 & 2799018 & 518617 & 30 & 29.6 & 30.8 & 45 \\
\hline 2 & Klaipeda & LT & 55.73 & 21.22 & 2935122 & 693250 & 6 & 36.6 & 29.0 & 25 \\
\hline 3 & Silute & LT & 55.35 & 21.47 & 2895754 & 715675 & 3 & 24.3 & 19.1 & 25 \\
\hline 4 & Viesvile & LT & 55.08 & 22.77 & 2880539 & 801057 & 11 & 23.2 & 26.4 & 25 \\
\hline 5 & Girionys & LT & 54.89 & 23.90 & 2873510 & 874874 & 20 & 24.3 & 22.4 & 20 \\
\hline 6 & Lazdijai & LT & 54.2 & 23.51 & 2797810 & 864120 & 43 & 28.1 & 16.4 & 15 \\
\hline 7 & Zagare & LT & 56.36 & 23.25 & 3024422 & 805011 & 25 & 67.7 & 24.0 & 15 \\
\hline 8 & Talsi & LV & 57.39 & 22.59 & 3128521 & 745582 & 17 & 30.7 & 28.6 & 35 \\
\hline
\end{tabular}

their deposition and surface ozone data from the Preila EMEP station were obtained. The monitored stands were located no further than $300 \mathrm{~km}$ from this EMEP station, which was the source of the longest data set on concentrations of acidifying compounds in this part of Europe, as well as their wet deposition and surface ozone. Preila EMEP station is under operation since 1981 (Girgzdiene et al. 2009, Sopauskiene \& Jasineviciene 2006). In this study, we used longer data sets from one station rather than shorter sets (data since 1994) from stations representing the considered regions. We assumed that the distance between the studied stands and the Preila EMEP station providing data on regional air pollution was not generally an important factor in detecting common effects of acidifying compounds and surface ozone on the growth of beech trees. It is known that short time data series may lead to misinterpretations of relationships between predict and response variables and, in the context of global change, may contribute to the significant uncertainties in this field (Klap et al. 2000, Serengil et al. 2011). Moreover, it was much more important to detect the significance of the temporal effect of regional pollution alone on beech growth over 1982-2010 period than to detect spatial effect over 1994-2010 period, because concentrations of air pollutants and deposition of acidifying compounds until 1994 were much higher and their effect on beech growth had to be more significant than that after 1994 (Augustaitis et al. 2014).

On the other hand, topography of the considered sites, especially site's longitude, was used in the analysis as a predict variable, which is related to some extent to the spatial variability of the considered pollutants. Main pollutant sources in this part of Europe are long-range transboundary air pollutants traveling with air masses from middle and western parts of Europe. Detailed data on variation in air concentration of acidifying compounds, acid deposition and surface ozone at the Preila EMEP station were presented in our earlier studies (Augustaitis et al. 2012, 2014).

More than 200 tree ring width series from eight European beech locations were chosen to meet the objectives of the study. Three beech stands were aggregated into one complex site in northeast Poland, Site No 1, in Latvia Site No 8 and also in Lithuania, Sites No 3 and 4 (Fig. 1). One stand represented data in the middle of Lithuania Girionys Site No 5 . The area of observation plots was $500 \mathrm{~m}^{2}$ each in Latvia and Poland, and $1000 \mathrm{~m}^{2}$ in Lithuania. Only in Lazdijai and Zagare (Lithuanian sites No 6 and 7), due to missing beech stands, individual beech trees were used for the analysis. The main stem and crown parameters (diameter at breast height, height, crown width, and crown length) of each beech tree were measured, and in addition wood samples were taken from randomly selected trees 
by a Pressler borer for tree-ring (annual radial increment) analysis. Main characteristics of the monitored beech stands are listed in Tab. 1.

Details on the preparation of tree stem borers and measurement technique was reported in earlier publications (Augustaitis et al. 2014, Juknys et al. 2014). Tree-ring width was measured to the nearest 0.01 $\mathrm{mm}$. The measurements were accomplished using a Lintab tree-ring measuring table and the TSAP software package ( $F$. Rinn, Engineering Office and Distribution, Heidelberg, Germany). The obtained individual tree-ring width series were synchronized by visual comparison of ring width graphs (Eckstein 1987) and statistically by calculating the coefficients of correlation (Baillie \& Pilcher 1973). The mean tree-ring series for each stand were calculated on the basis of individual tree-ring series of 2030 sampled beech trees. The standardization of these tree-ring series and the elimination of age trend (Holmes 1994) were performed by fitting a third-degree polynomial curve. Indexes of annual increment were calculated by computing the differences between the measured ring width and its approximated value. The values obtained (in $\mathrm{mm}$ ) allowed to evaluate the significance of the increment amplitude to the sustainable growth of beech trees under the presses of unfavorable environmental factors.

Meteorological data were obtained from meteorological stations nearest to the monitored beech stands (about 10-15 km apart). Mean monthly values of air temperature and sum of precipitation of a month were chosen as the main factors which could result in beech tree growth peculiarities outside their distribution range (Cook 1987, Eckstein 1989, Cook \& Kairiukštis 1990, Schweingruber 1996, McLaughlin et al. 2002, Juknys et al. 2014). To detect differences in the variability of air temperature and precipitation amount at the considered sites, two different periods were selected: (i) the growing season - from April through September; and (ii) the dormant period - from October through March. Simple Pearson's correlation analysis was applied to detect significant relationships between meteorological variables and the increment indexes of beech trees, based on the following assumptions: - existing causative relationship between predictor and response variables should be established by means of simple mathematical methods;

- no causative relation exists if relationships between predictor and response variables are not significant.

The problem remains only that significant relationships not always reflect causative relationship between the predictor and the response variables, because some coincidence in the nature always exists, or predictors frequently can be response variables due the impact of "real" predict variables which is unknown.
To solve this problem the linear multiple regression technique implemented in the statistical sofware STATISTICA ${ }^{\circledR} 7.0$ was applied. Single monthly values on temperature or precipitation amount, along with mean air concentration of surface ozone during growing season, and annual air concentrations of acidifying compounds and their amount of deposition, were included in the models. During this procedure, the selected parameters were excluded from the regression model by a stepwise procedure based on their lowest level of significance (Draper \& Smith 1998). Finally, variables with a high level of significance $(\mathrm{p}<$ 0.05 ) were used to run the models. These parameters were evaluated as key factors limiting beech growth outside their distribution range. The goodness-of-fit of each model was assessed by determining the coefficient of determination $\left(R^{2}\right)$ and the level of statistical significance ( $p)$.

Comparison of the results obtained at the site on the edge of the beech natural distribution range (in Poland) with those obtained at sites outside the range (in Lithuania and Latvia), enabled to assess the sensitivity of beech trees to all possible unfavorable environmental factors, and to predict their resistance to: (a) frost during the dormant period; (b) drought and heat during the vegetative period; (c) acidifying compounds; and (d) surface ozone.

\section{Results and discussion}

Geographical distribution of the beech trees depends on their low resistance to summer drought at low altitude/latitude, and low temperatures (late frost and short length of the growing season) at high altitude/latitude (Maxime \& Hendrik 2011). Therefore, the effect of summer drought and winter frost in conjunction with air concentration of acidifying compounds and surface ozone concentration was ana-

Tab. 2 - Main statistical parameters of single-factor ANOVA of mean temperature during dormant, growing season, and annual periods across the selected sites in latitudinal and longitudinal directions.

\begin{tabular}{lllccc}
\hline Direction & Variable & $\begin{array}{l}\text { Site no / } \\
\text { Statistics }\end{array}$ & $\begin{array}{c}\text { Annual } \\
(\mathbf{n = 5 8 )}\end{array}$ & $\begin{array}{c}\text { Dormant } \\
(\mathbf{n = 5 8 )}\end{array}$ & $\begin{array}{c}\text { Vegetation } \\
(\mathbf{n}=\mathbf{5 8})\end{array}$ \\
\hline Latitudinal & Mean & No 1 & 7.70 & 2.54 & 12.86 \\
& temperature & No 2 & 7.27 & 1.48 & 13.06 \\
& at site & No 8 & 5.94 & -0.31 & 12.20 \\
& ANOVA: & SS & 95.9 & 238.1 & 23.2 \\
& Single Factor & df & 2 & 2 & 2 \\
& statistics & MS & 47.96 & 119.03 & 11.59 \\
& & F & 50.7 & 54.7 & 17.9 \\
& & F crit & 3049 & 3049 & 3049 \\
Longitudinal & P-value & $5.2 \times 10^{-18}$ & $4.5 \times 10^{-19}$ & $9.0 \times 10^{-08}$ \\
& Mean & No 2 & 7.27 & 1.48 & 13.06 \\
& temperature & No 3 & 6.97 & 0.65 & 13.29 \\
& at site & No 4 & 6.14 & -0.61 & 12.88 \\
& & No 5 & 6.32 & -0.26 & 13.55 \\
& ANOVA: & SS & 41.3 & 154.0 & 14.8 \\
& Single Factor & df & 3 & 3 & 3 \\
& statistics & MS & 13.76 & 51.33 & 4.93 \\
& & F & 13.0 & 19.9 & 6.91 \\
& & F crit & 2644 & 2644 & 2644 \\
\hline
\end{tabular}

lyzed to investigate beech tree growth peculiarities on the edge of their distribution range.

\section{Spatial and temporal changes in} meteorological parameters

The long-term mean annual temperature at all sites fluctuated between +5.94 and $+7.7{ }^{\circ} \mathrm{C}$, with an increasing trend in the period $1950-2010$ by approximately $0.026^{\circ} \mathrm{C}$ per year (Tab. 2). This increase was in full agreement with data presented by the SRES A1 B Project, and was most pronounced during the dormant period (October-March), with an increase of $0.03^{\circ} \mathrm{C}$ per year $(p=0.034)$. During the growing season (April-September) mean monthly temperature showed a tendency towards increasing $0.022^{\circ} \mathrm{C}$ per year $(p=0.068)$.

Spatial variation in mean temperature of the considered periods was determined (Fig. 2). Moving northbound along the Baltic seaside, mean annual temperature decreased significantly from $7.7^{\circ} \mathrm{C}$ at Kurtuzy, Poland (Site No. 1) to $5.94^{\circ} \mathrm{C}$ at Talsy, Latvia (Site No. 8); moving from Lithuanian west to east, temperature decreased from 7.27 ${ }^{\circ} \mathrm{C}$ at Klaipeda (Site No. 2) to $6.2{ }^{\circ} \mathrm{C}$ in central Lithuania (Sites No. 4 and 6 - Tab. 2). during October-March (dormant period) and April-September (growing season) occurred following the same tendencies. Temperature decreased moving both north- and eastbound. All detected temporal variations were statistically significant $(p<0.05)$.

Annual amount of precipitation was in the range $620-770 \mathrm{~mm}$, but significant differences were found moving from west to east. decreasing from $720-760 \mathrm{~mm}$ at the seaside site No 2 in Klaipeda to $620 \mathrm{~mm}$ at Girionys $\mathrm{No} 5$ site in the Kaunas district (Fig. 3). A statistically significant $(p<0.05)$ decrease in precipitation during both the Spatial variation in mean air temperature 

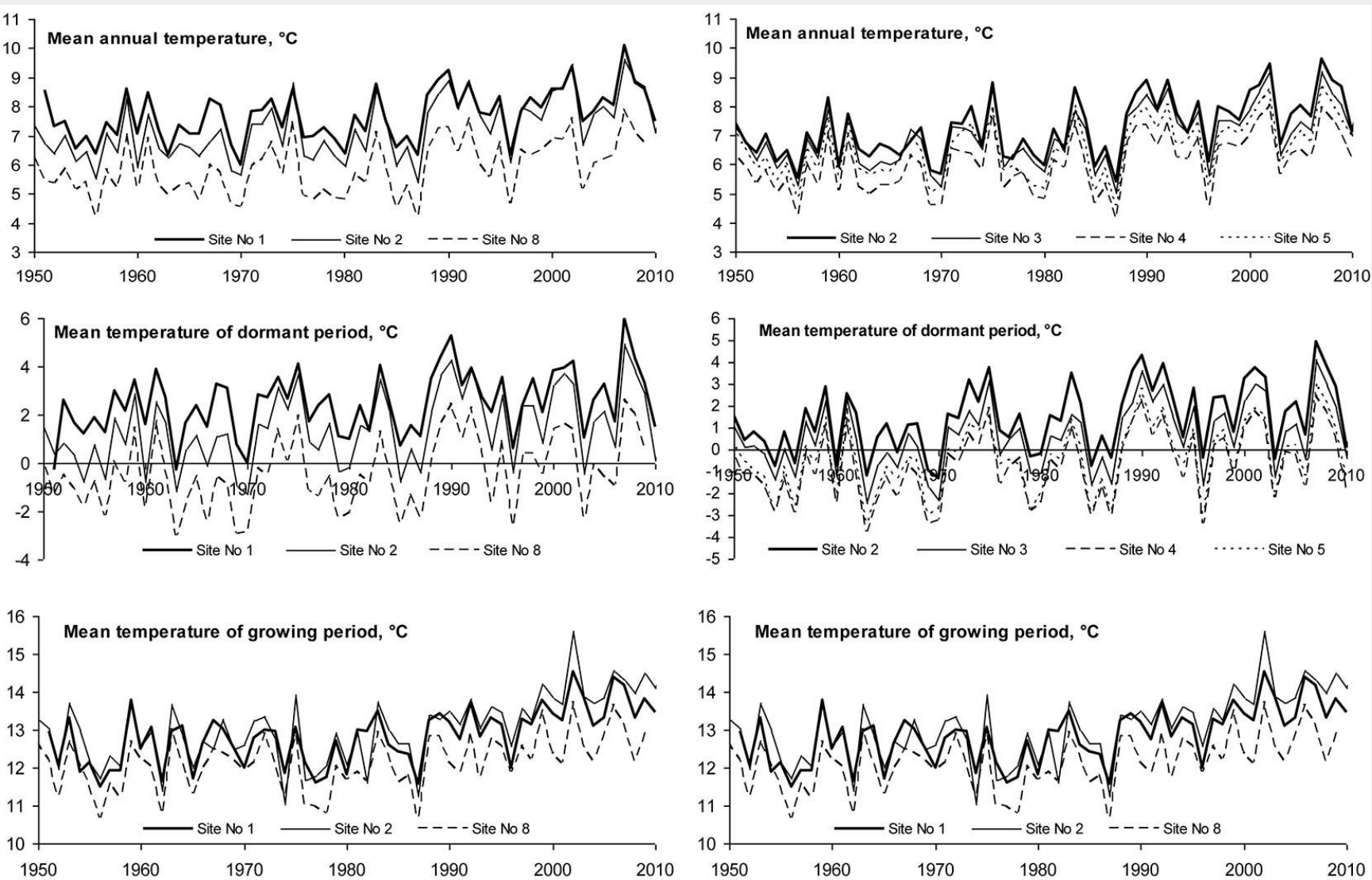

Fig. 2 - Latitudinal and longitudinal variation of the mean temperature during dormant, growing season and annual periods.
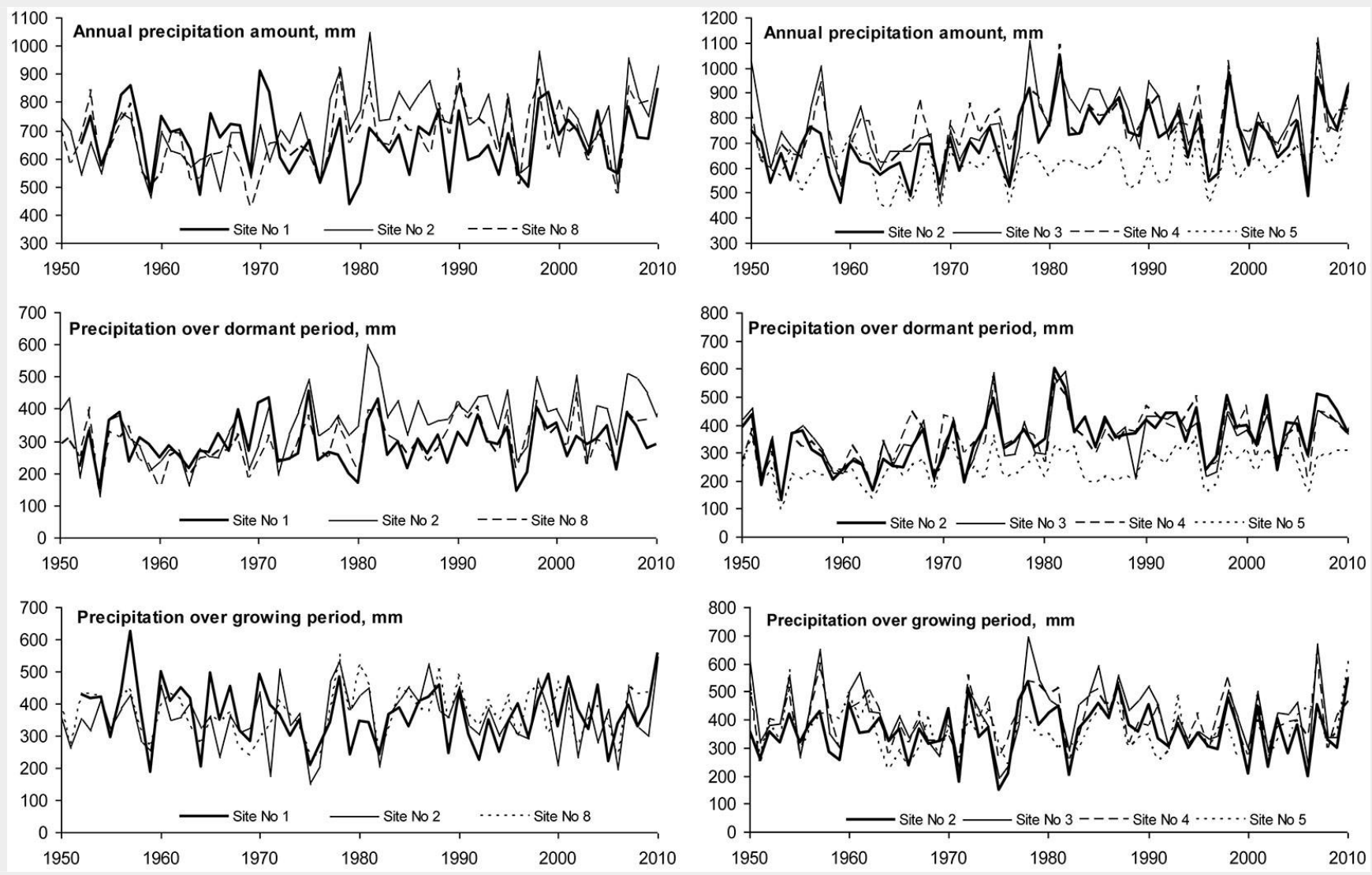

Fig. 3 - Latitudinal and longitudinal variability of precipitation during the dormant, growing seasons and annual periods. 
growing season (April-September) and dormant (October-March) period was also found moving in this direction (Tab. 3).

The intensity of trends in temporal variation of the considered meteorological parameters differed significantly during the entire period of investigation at the sites (Fig. 4). Until 1985 the annual mean temperature was rather stable and only during the dormant period there was a trend of increase by approximately $0.01^{\circ} \mathrm{C}$ per year. After 1985 the situation changed substantially: mean temperature during the growing season started increasing by approximately $0.06{ }^{\circ} \mathrm{C}$ per year, and during the dormant period increased from $0.025{ }^{\circ} \mathrm{C}$ per year at Site No. 2 up to $0.065{ }^{\circ} \mathrm{C}$ per year at Site No. 6 . Such changes in mean temperature resulted in an increase in the annual mean temperature by approximately $0.05{ }^{\circ} \mathrm{C}$ per year and could have had a significant impact on beech migration to the east.

Lack of moisture occurred in 1976, 1977, 1997 and 2006, when the annual amount of precipitation was $\leq 600 \mathrm{~mm}$, representing only about $30-40 \%$ of the optimum value for beech whose growth requires $1500 \mathrm{~mm}$ according to Teissier du Cros et al. (1981) (Fig. 3). The years with excessive humidity were 1978-1991, 1998, 2005 and 2007, when annual precipitation was $>1000 \mathrm{~mm}$, representing approximately $60 \%$ of the optimum for beech growth.

The analysis of annual precipitation revealed an increase of about 1-2 mm per year during the whole period considered, with the exception of Site No. 1, where precipitation remained stable. Trends of variation in precipitation during the dormant as well as growing seasons did not differ significantly. Increase in precipitation showed no significant spatial variation, therefore its effect could have had only local character.

\section{Beech tree growth}

At lower altitude sites in central Europe, there were clear increasing growth trends, whereas at higher altitudes almost all sites showed slightly decreased growth potential, especially in recent decades (Dittmar et al. 2003). On the edge of the natural distribution range, beech tree ring width series revealed different tree growth scenarios, in particular since 1992-1994. Up to these years beech growth slightly decreased at all sites, according to well-known ageing regularities, by approximately 0.02 $\mathrm{mm}$ per year (Fig. 5). These findings agreed well with the findings from southern Europe, where decreased beech growth was detected as a result of increasing temperatures during the growing season and insufficient increase in precipitation to counterbalance the negative effects of increased temperatures on tree growth (Jump et al. 2006). At sites close to the Baltic sea this regular pattern continued after 1992-1994 as well (Fig. 5a), while beech tree growth at more eastern sites revealed a trend
Tab. 3 - Main statistical parameters of single-factor ANOVA of precipitation amount during the dormant, growing seasons and annual periods across the selected sites in latitudinal and longitudinal directions.

\begin{tabular}{lllccc}
\hline Direction & Variable & $\begin{array}{l}\text { Site no/ } \\
\text { Statistics }\end{array}$ & $\begin{array}{c}\text { Annual } \\
(\mathbf{n}=59)\end{array}$ & $\begin{array}{c}\text { Dormant } \\
(\mathbf{n}=59)\end{array}$ & $\begin{array}{c}\text { Vegetation } \\
(\mathbf{n}=59)\end{array}$ \\
\hline Latitudinal & Precipitation & No 1 & 663 & 294 & 369 \\
& amount at & No 2 & 710 & 351 & 359 \\
& site & No 8 & 680 & 301 & 379 \\
& ANOVA: & SS & 66517 & 114436 & 11866 \\
& Single Factor & df & 2 & 2 & 2 \\
& statistics & MS & 33258 & 57217 & 5933 \\
& & F & 2407 & 8688 & 0.784 \\
& & F crit & 3049 & 3049 & 3049 \\
Longitudinal & P-value & 0.0931 & 0.0003 & 0.4581 \\
& Precipitation & No 2 & 710 & 351 & 359 \\
& amount at & No 3 & 762 & 348 & 413 \\
& site & No 4 & 771 & 361 & 410 \\
& & No 5 & 618 & 252 & 365 \\
& ANOVA: & SS & 867794 & 454681 & 147152 \\
& Single Factor & df & 3 & 3 & 3 \\
& statistics & MS & 289265 & 151560 & 49051 \\
& & F & 19.89 & 19.71 & 5405 \\
& & F crit & 2644 & 2644 & 2644 \\
& & P-value & $1.6 \times 10^{-11}$ & $2.0 \times 10^{-11}$ & 0.0013 \\
\hline
\end{tabular}

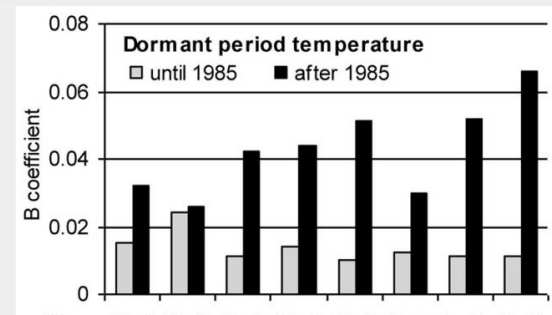

Sites No 1 No 2 № 3 No 4 № 5 № 7 No 8 № 6

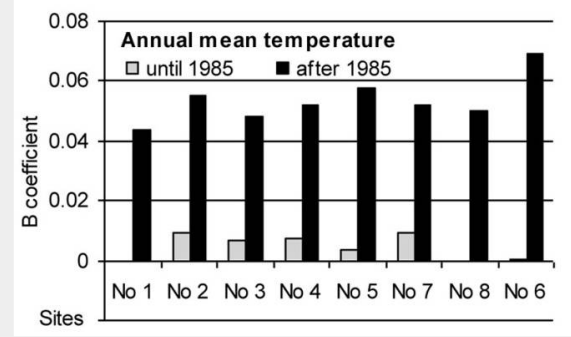

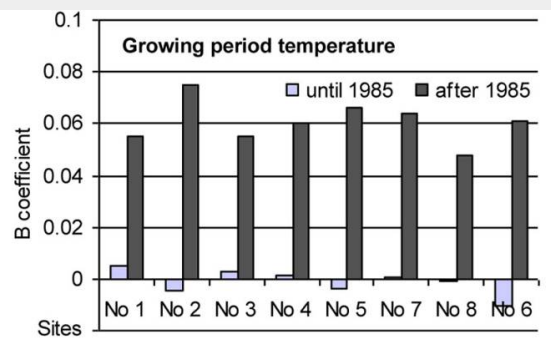

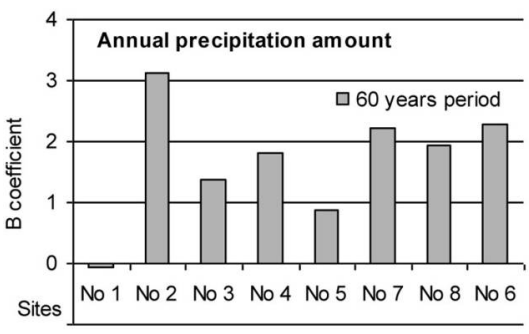

Fig. 4 - Trends of the intensity of variation (B coefficient of the linear regression) and its slopes (positive: increase; negative; decrease) for the considered meteorological parameters over the periods $1955-1985$ and $1985-2010$.

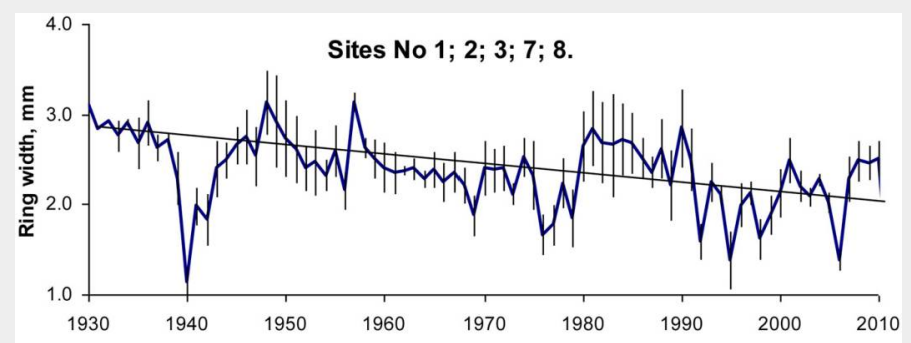

Fig. 5 - Annual increment of beech trees and standard errors of their ring widths on the edge and outside of their distribution range.

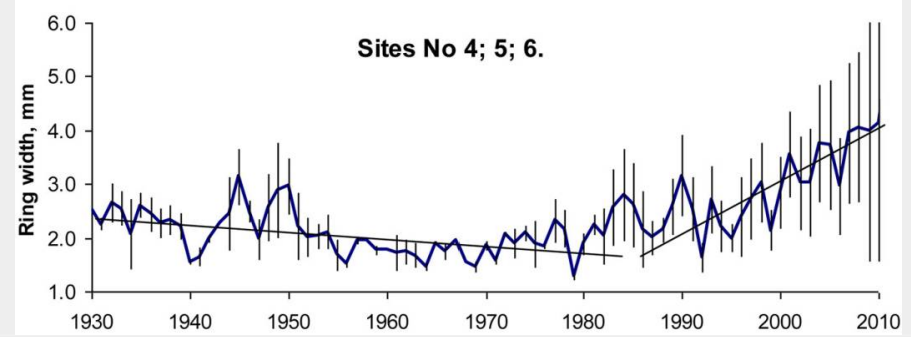




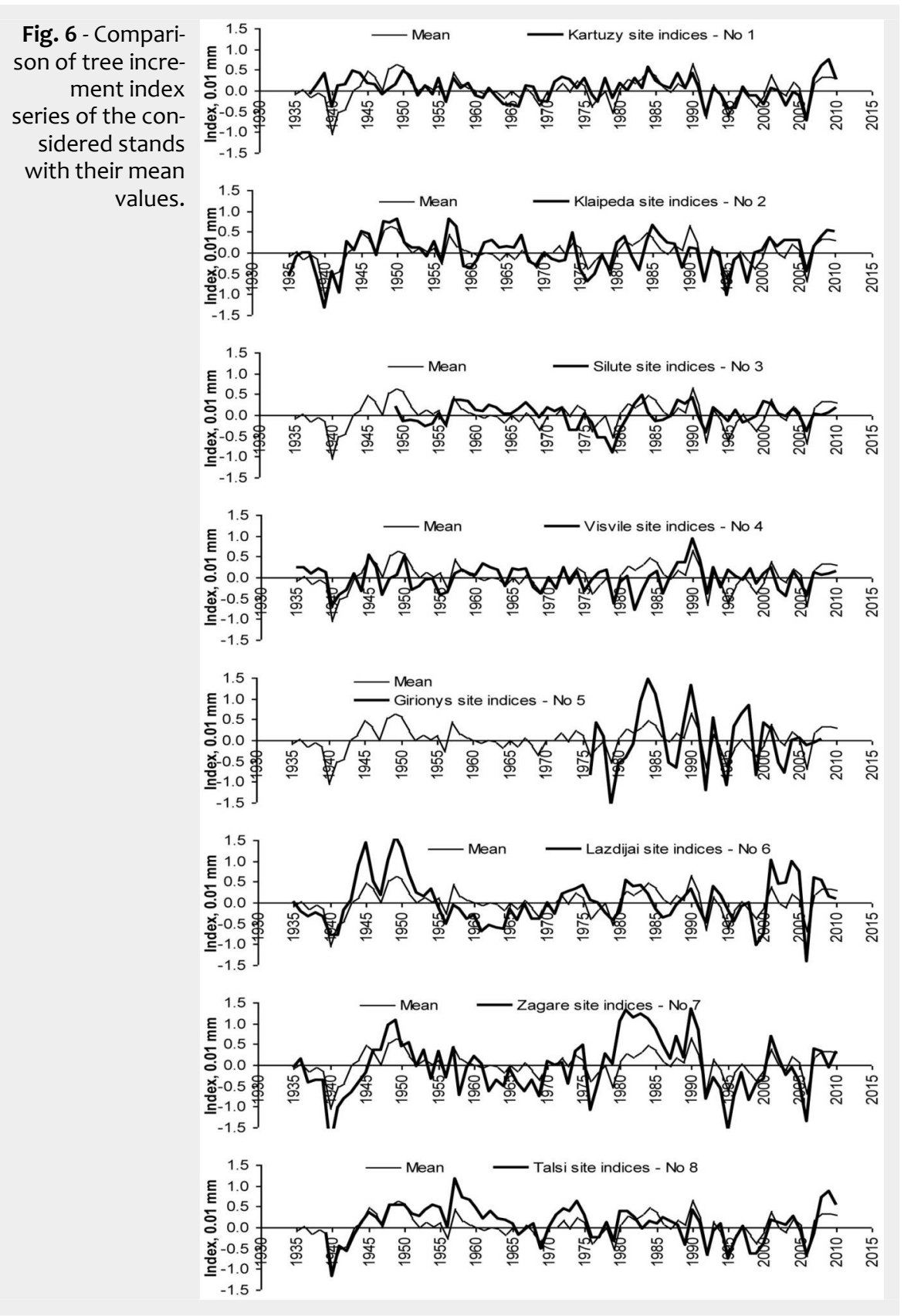

towards increasing (Fig. 5b), increasing at the same time the amplitude of variation. This growth trend is not consistent with recently detected trends in Central and South Europe (Solberg et al. 2009, Aertsen et al. 2014) and could be attributed to the effect of climate change.

In general the most favorable years for beech tree growth were found to be the middle and the end of 1940s, also 1957, the period between 1981 and 1990 and the decade following 2001. Significant decrease in increment was detected in 1940, 1956 and 1979, due to frost in winter, and in

Tab. 4 - Inter-correlation between tree ring indexes of beech trees from different locations. Statistically significant interaction in bold $(p<0.05)$.

\begin{tabular}{lcccccccc}
\hline $\begin{array}{l}\text { Site } \\
\text { number }\end{array}$ & No_8 & No_2 & No_1 & No_7 & No_3 & No_4 & No_6 & No_5 \\
\hline No_8 & - & 0.645 & 0.652 & 0.498 & 0.267 & 0.182 & 0.386 & 0.270 \\
No_2 & - & - & 0.478 & 0.469 & 0.284 & 0.249 & 0.386 & 0.276 \\
No_1 & - & - & - & 0.626 & 0.240 & 0.256 & 0.479 & 0.428 \\
No_7 & - & - & - & - & 0.219 & 0.127 & 0.486 & 0.394 \\
No_3 & - & - & - & - & - & 0.347 & 0.151 & 0.430 \\
No_4 & - & - & - & - & - & - & 0.175 & 0.464 \\
No_6 & - & - & - & - & - & - & - & 0.205 \\
Mean & 0.763 & 0.738 & 0.786 & 0.801 & 0.447 & 0.412 & 0.707 & 0.470 \\
\hline
\end{tabular}

1992, 1994 and 2006, mainly due to drought during the growing season (Fig. 3). Furthermore, it should be noticed that the heat during the growing season 2007 had no negative effect on beech stem increment, while heat in 2003 which damaged the forests in western and southern Europe (UN-ECE 2013) was not pronounced in the study region (UNEP 2004).

Correlation analysis between calculated tree ring indexes indicated the same beech tree growth peculiarities at sites close to the Baltic Sea (Site No 1, 2, 8). Correlation coefficients between these data series were statistically significant $(p<0.05)$. With increasing distance from the sea eastbound, the difference in beech tree growth increased (Fig. 6) and the significance of relationships between tree ring indexes series of the considered sites decreased (Tab. 4).

\section{Correlation analysis between}

meteorological variables and beech tree increment indexes

Correlation analysis revealed a positive relationship between warmer winters (December-February) and beech increment indexes as well as negative between mean temperature of June and beech increment indexes (Fig. 7). Increment indexes obtained at the site of natural distribution (Poland, Site No. 1) significantly and positively correlated with warmer dormant period. Moving to the north along the seaside, the significance of this relationship increased, especially at Lithuanian Sites No 7 and Latvian Site No 8. Warmer April and May seemed to have also positive impact on beech growth, especially at most eastern Lithuanian sites Nos 5 and 6 . It could be explained by an earlier budburst which increases the probability of late frost impact in temperate and boreal zones (Hanninen 2006), resulting in the reduction of tree increment.

High temperatures during July-September usually had a negative impact on beech stem radial increment of the following year (Dittmar et al. 2003). In our case, we detected negative relationships between June's mean temperature and increment indexes of beech trees. The significance of these negative relationships increased moving eastward, and the most significant value was reached at the most eastern site, i.e., Site No. 5 (Kaunas District - Lithuania).

Contrary to the statement that a positive effect of precipitation during the growing period could be detected only at high altitude (Maxime \& Hendrik 2011), the results obtained revealed that these positive relationships could be detected also at lower altitude, but outside the beech natural distribution range in northeastern Europe (Fig. 7). It should be noticed that the relationship between the precipitation amount of the rest months and increment indexes was much less significant ( $p>0.05)$. Tree water deficit during the growing season negatively affects tree ring formation by in- 
hibiting cell division and enlargement (Zweifel et al. 2006), and reduces carbon assimilation via stomatal control of photosynthesis and transpiration (Breda et al. 2006) - moving toward the northeast the significance of this effect increased. The least significant relationships between precipitation amount in June and annual increment of beech were detected at Sites No 1 and 3 , and the most significant at Site No 7. Previously reported growth-climate correlation analyses yielded negative correlations with summer temperature and positive correlations with precipitation at the same time (Tegel et al. 2014) - this was consistent with our results. The lack of humidity and heat during June-July was one of the key factors limiting the migration of beech trees northward. These findings agreed well with the known sensitivity of beech growth to drought in the period between budburst and the end of July (Dittmar et al. 2003, Lebourgeois et al. 2005, Mund et al. 2010, Scharnweber et al. 2011). A cold dormant period especially winter months is a likely accompanying factor limiting beech tree growth and distribution toward the northeast of Europe.

Recently, beech tree growth decline has become a widespread phenomenon in Europe. Higher temperatures accompanied with lack of humidity during the vegetative period may lead to a rapid decline in the growth of range-edge populations and to the consequent retreat of the compounds distribution in southern Europe (Jump et al. 2006). Beech does not tolerate extreme water stress. Therefore, during the growing period, especially June and July, low temperatures and high precipitation supported the formation of wide tree rings. Warm, sunny and dry early autumn also promoted radial growth at the beginning of the following season (Dittmar et al. 2003).

The results of the correlation analysis revealed that in the most northeastern location of beech distribution range the lack of humidity (precipitation) in the middle of the vegetative period (July), frost in winter, lower temperatures in early spring (March-April) and higher temperatures in June limited the growth of beech trees.

Relationships between beech increment indexes and air concentration of acidifying compounds, their deposition, and surface ozone

The recent trend of increasing growth of forest trees is often attributed not only to climate change and increased atmospheric concentrations of $\mathrm{CO}_{2}$, but also to the increased nitrogen deposition (Braun et al. 2010, Bontemps et al. 2011), especially for nitrogen-limited soils (Aertsen et al. 2014). Sulfur and its acid deposition both had negative effects on tree health and productivity, but showed mostly positive slopes with tree growth only due to their high correlation with nitrogen deposition (Solberg et al. 2009) whose effect is well estab-
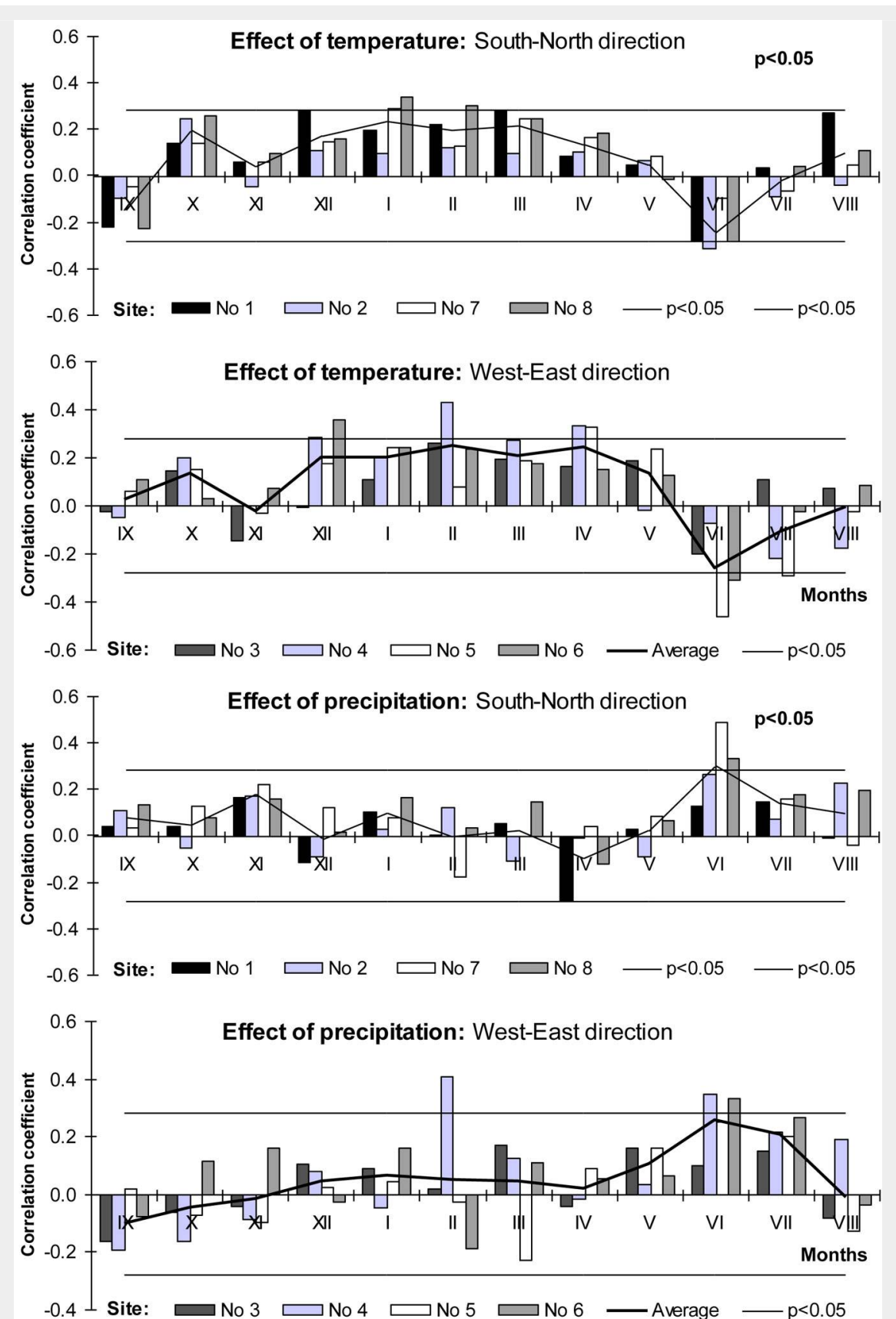

Fig. 7 - Relationships between meteorological parameters and beech tree increment indices.

lished. In areas with high levels of nitrogen deposition the growth of beech trees is mitigated, and at lower fertility sites the nitrogen deposition has a fertilizing effect on beech growth (Aertsen et al. 2014, Thomas et al. 2002, 2006). Our results suggest that $\mathrm{N}$ deposition on the edge and outside of beech distribution range could have also positive effect on beech tree stem increment. Relationships between increment indexes and $\mathrm{N}$ deposition (ammonium and nitrate) were statistically significant, but only at sites near to the Baltic Sea. Precipitation, which is the key factor of total wet deposition (Augustaitis 2011), is partly responsible for that reaction of beech tree growth. On the other hand, the positive relationship between ammonium concen- tration in precipitation and increment indexes was statistically significant at 5 out of the 8 monitored stands.

Beech is one of the most sensitive tree species to the phytotoxic effect of surface ozone (Matyssek \& Innes 1999, Matyssek et al. 2007, 2010, Pretzsch et al. 2010). The results obtained in this study fully confirmed such evidence. The relationships between surface ozone and beech tree ring indexes showed the highest negative significance rate. A higher concentration of ozone limited beech tree growth near the sea (Sites No 1, No 2, No 8) as well as sites close to it (Site No 7). Most likely, spatial variation in surface ozone concentration (which was not accepted in the present study since data from one EMEP station 

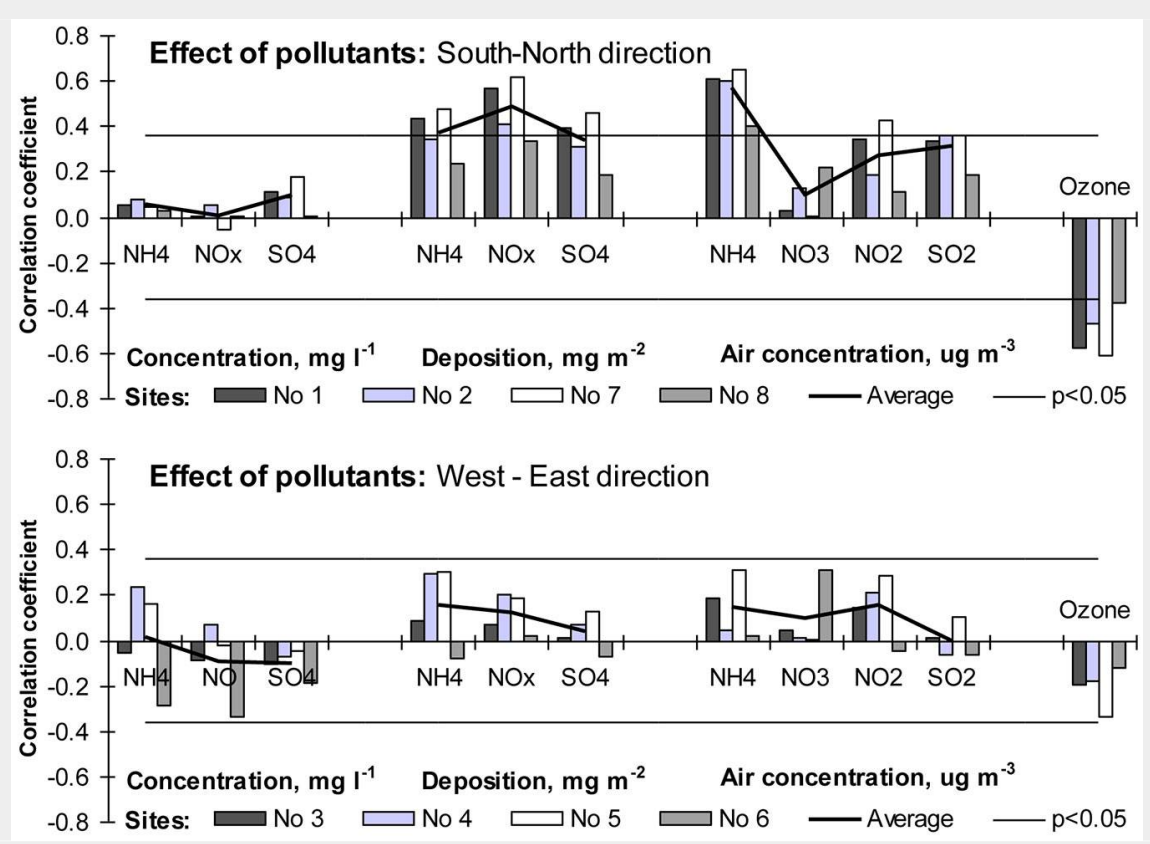

Fig. 8 - Relationships between beech tree increment indices and air concentration of surface ozone, acidifying species and acid deposition.

was used) could have had an essential
effect on the significance of the detected relationships (Fig. 8).

Integrated effect of environmental factors on beech increment indexes

The integrated effect of meteorological parameters, air concentration of surface ozone, along with acidifying compounds and their deposition, on beech tree incre- ment indexes in northeast Europe was assessed by multiple regression analysis, whose results are reported in Tab. 5. The reduction in beech tree increment significantly correlated with frost in winter and heat in summer, as well as with more abundant precipitation in winter and drought in summer. Negative effect of these meteorological variables reinforced the effect of surface ozone and sulphur deposition, whi- le nitrate air concentration and its deposition seemed to have positive effect on tree increment. The detected key environmental parameters explained up to $70-80 \%$ variation in beech tree increment indexes at the studied sites separately (Models 1-8). Similar results were obtained in our earlier study, i.e., air concentrations of sulfur dioxide and ozone, together with sulfur deposition, limited the growth of Scots pine trees, and only nitrate deposition and its air concentration had a positive effect on pine growth (Augustaitis et al. 2003, 2007). The same reactions to environmental factors most likely could explain why pine and beech trees grow together very well outside the beech natural range.

The general model developed in this study revealed that the detected key variables explained up to $50 \%$ of the total variation in beech increment indexes on the edge and outside their natural distribution range. Separate analyses carried out using the models at the sites considered revealed that coefficient of determination $\left(R^{2}\right)$ ranged from 30 to $40 \%$ at Sites No 3 and -4 up to $60-70 \%$ at Sites Nos 1, 7 and 8 (Fig. 9). It is worth to notice that increment indexes correlated best with environmental factors in Poland (Site No 1, natural growth conditions) and at the most northern sites (Site No 8 in Latvia, and Site No 7 in Lithuania), as well as at the most eastern locations (Sites No 5 and 6).

Air temperature effect on the variation of increment indexes was higher than the effect of precipitation (about 12\% and 9\%, respectively). Their integrated effect could explain up to $24 \%$ of the total variation in beech tree increment indexes. The effect

Tab. 5 - Key predicting variables of beech tree increment indexes and main statistics of the developed multi-regression models. $\left({ }^{*}\right)$ : the number of cases applied for the model: $N=A+B+1$, where $A$ is the number of predicting variables and $B$ represents the degree of freedom; $N=29$ - years from 1982 to 2010; $N=230$ - 8 sites per $27-29$ years. Relationship: ( $\uparrow$ ) positive; ( $\downarrow$ ) negative; in all cases $p<0.05$.

\begin{tabular}{|c|c|c|c|c|c|c|c|c|c|c|c|c|c|c|c|c|}
\hline \multirow{2}{*}{$\begin{array}{l}\text { Site No/ } \\
\text { Parameter }\end{array}$} & \multirow{2}{*}{$\begin{array}{c}\text { Model* } \\
(A-B)\end{array}$} & \multirow[t]{2}{*}{ Long } & \multicolumn{4}{|c|}{ Monthly temperature } & \multicolumn{4}{|c|}{ Precipitation amount } & \multicolumn{2}{|c|}{$\begin{array}{c}\text { Air } \\
\text { concentration }\end{array}$} & \multicolumn{2}{|c|}{ Deposition } & \multicolumn{2}{|c|}{ Statistics } \\
\hline & & & XII & II & VI & VII & XII & $X$ & V & VII & $\mathrm{O}_{3}$ & $\mathrm{NO}_{3}^{-}$ & $\mathrm{SO}_{4}{ }^{2-}$ & $\mathrm{NO}_{3}{ }^{-}$ & $\mathrm{R}^{2}$ & $\mathrm{p}$ \\
\hline 1 & $(8-20)$ & - & $\uparrow$ & $\uparrow$ & $\downarrow$ & - & $\downarrow$ & - & - & $\uparrow$ & $\downarrow$ & - & $\downarrow$ & $\uparrow$ & 0.715 & 0.0006 \\
\hline 2 & $(5-23)$ & - & $\uparrow$ & - & $\downarrow$ & - & - & - & - & $\uparrow$ & $\downarrow$ & $\uparrow$ & - & - & 0.621 & 0.0007 \\
\hline 3 & $(7-21)$ & - & - & $\uparrow$ & $\downarrow$ & - & - & $\downarrow$ & - & $\uparrow$ & $\downarrow$ & - & $\downarrow$ & $\uparrow$ & 0.639 & 0.0019 \\
\hline 4 & $(6-22)$ & - & - & $\uparrow$ & $\downarrow$ & $\downarrow$ & - & - & - & $\uparrow$ & - & - & $\downarrow$ & $\uparrow$ & 0.623 & 0.0007 \\
\hline 5 & $(7-19)$ & - & - & $\uparrow$ & $\downarrow$ & $\downarrow$ & - & - & $\uparrow$ & - & $\downarrow$ & - & $\downarrow$ & $\uparrow$ & 0.733 & 0.0004 \\
\hline 7 & $(9-19)$ & - & $\uparrow$ & $\uparrow$ & $\downarrow$ & - & - & $\downarrow$ & $\uparrow$ & - & $\downarrow$ & $\uparrow$ & $\downarrow$ & $\uparrow$ & 0.829 & 0.0000 \\
\hline 8 & $(7-21)$ & - & $\uparrow$ & - & $\downarrow$ & - & - & - & - & $\uparrow$ & $\downarrow$ & $\uparrow$ & $\downarrow$ & $\uparrow$ & 0.712 & 0.0003 \\
\hline Temperature & $(3-226)$ & - & $\uparrow$ & - & $\downarrow$ & $\downarrow$ & - & - & - & - & - & - & - & - & 0.120 & 0.0000 \\
\hline Precipitation & $(2-227)$ & - & - & - & - & - & - & - & $\uparrow$ & $\uparrow$ & - & - & - & - & 0.097 & 0.0000 \\
\hline Meteorology & $(4-225)$ & - & - & $\uparrow$ & $\downarrow$ & - & - & - & $\uparrow$ & $\uparrow$ & - & - & - & - & 0.239 & 0.0000 \\
\hline Concentration & $(2-227)$ & - & - & - & - & - & - & - & - & - & $\downarrow$ & $\uparrow$ & - & - & 0.159 & 0.0000 \\
\hline Deposition & $(2-227)$ & - & - & - & - & - & - & - & - & - & - & - & $\downarrow$ & $\uparrow$ & 0.090 & 0.0001 \\
\hline Pollution & $(4-225)$ & - & - & - & - & - & - & - & - & - & $\downarrow$ & $\uparrow$ & $\downarrow$ & $\uparrow$ & 0.227 & 0.0000 \\
\hline Deposition & $(8-221)$ & - & $\uparrow$ & $\uparrow$ & $\downarrow$ & - & - & $\downarrow$ & $\uparrow$ & $\uparrow$ & $\downarrow$ & $\uparrow$ & - & - & 0.375 & 0.0000 \\
\hline Concentration & $(8-221)$ & - & - & $\uparrow$ & $\downarrow$ & - & $\downarrow$ & $\downarrow$ & $\uparrow$ & $\uparrow$ & - & - & $\downarrow$ & $\uparrow$ & 0.329 & 0.0000 \\
\hline Nitrogen & $(8-211)$ & $\uparrow$ & $\uparrow$ & $\uparrow$ & $\downarrow$ & - & - & $\downarrow$ & $\uparrow$ & $\uparrow$ & - & $\uparrow$ & - & - & 0.273 & 0.0000 \\
\hline $\mathrm{S}$ & $(7-212)$ & $\uparrow$ & $\uparrow$ & $\uparrow$ & $\downarrow$ & - & - & - & $\uparrow$ & $\uparrow$ & - & - & $\downarrow$ & - & 0.259 & 0.0000 \\
\hline $\mathrm{S}+\mathrm{O}_{3}$ & $(9-210)$ & $\uparrow$ & $\uparrow$ & $\uparrow$ & $\downarrow$ & - & $\downarrow$ & - & $\uparrow$ & $\uparrow$ & $\downarrow$ & - & $\downarrow$ & - & 0.364 & 0.0000 \\
\hline $\mathrm{O}_{3}$ included & $(8-211)$ & $\uparrow$ & $\uparrow$ & $\uparrow$ & $\downarrow$ & - & $\downarrow$ & - & $\uparrow$ & $\uparrow$ & $\downarrow$ & - & - & - & 0.333 & 0.0000 \\
\hline $\mathrm{O}_{3}$ excluded & (10-219) & $\uparrow$ & $\uparrow$ & $\uparrow$ & $\downarrow$ & - & - & $\downarrow$ & $\uparrow$ & $\uparrow$ & - & $\uparrow$ & $\downarrow$ & $\uparrow$ & 0.364 & 0.0000 \\
\hline Meteorology & $(5-204)$ & $\uparrow$ & - & $\uparrow$ & $\downarrow$ & - & - & - & $\uparrow$ & $\uparrow$ & - & - & - & - & 0.252 & 0.0000 \\
\hline Longitude & (10-219) & - & $\uparrow$ & $\uparrow$ & $\downarrow$ & - & - & $\downarrow$ & $\uparrow$ & $\uparrow$ & $\downarrow$ & $\uparrow$ & $\downarrow$ & $\uparrow$ & 0.454 & 0.0000 \\
\hline
\end{tabular}


of surface ozone, acidifying compounds in the air and their acid deposition showed very similar pattern. The explanatory power of surface ozone and air concentration of nitrate was higher than that of sulphur and nitrate deposition. Their integrated effect did not differ from the effect of meteorological variables. Combined with the meteorological parameters, the air concentration of the considered contaminants explained up to $38 \%$ of the total variation in beech growth indexes, while acid deposition only up to $33 \%$. The positive effect of nitrate in conjunction with meteorology is higher than the negative effect of sulphur deposition, which increased the amount of variance accounted for meteorology by $0.7 \%$ only. Notwithstanding, this the effect was significant for both these contaminants $(p<0.05)$.

The negative relationship between the precipitation in October-December and the increment indexes are difficult to be interpreted. The fact that precipitation is responsible for the total deposition level could be a possible explanation (Augustaitis et al. 2010a). Over the winter period, the air concentration of acidifying compounds usually reach the highest values, i.e., more abundant precipitation result in the highest amount of acid deposition. This factor should affect trees condition in general, directly through the effect on tree foliage and indirectly through the effect on soil (Augustaitis et al. 2010b).

The results of this study also confirmed that European beech is one of the most sensitive tree species to the phytotoxic effect of surface ozone. Although an accurate assessment of the effect of ozone on trees may be obtained only by measuring the ozone flux (Matyssek et al. 2010, Paoletti et al. 2010), multi-regression models applied in this study revealed that surface ozone can explain up to $12-13 \%$ of the total variation in beech increment indexes. It is known that reduced temperatures, shorter growing seasons and reduced nutrient supply with increased altitude can negatively affect growth rates (Coomes \& Allen 2007, Dittmar et al. 2006, Körner 2007). The same trend was expected with increasing longitude, but the opposite effect was found in this investigation. The relationship between longitude and beech increment was positive, and its effect on the variation of growth indexes exceeded $3 \%$. However, moving eastbound outside the beech range, not only maximum values of increment indexes increase, but their minimal values also decrease. Therefore, high amplitude of variation of beech tree increment (Fig. 10) may be interpreted as the key indicator of a decreased resiliency as well as resistance of beech trees to the effect of unfavorable climatic factors. Despite very high growth rates over the favorable periods, beech trees outside their natural range showed increments close to zero in unfavorable periods.
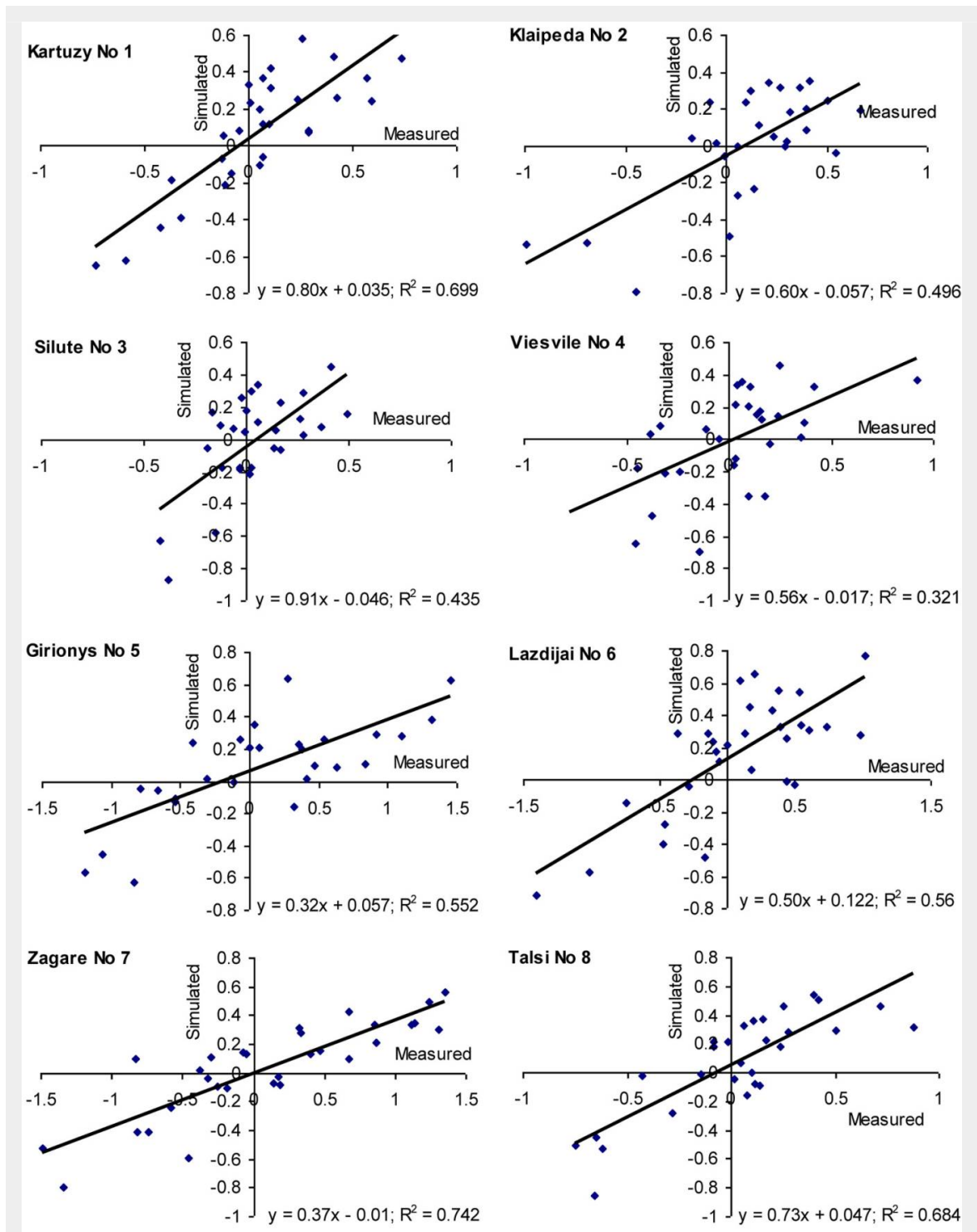

Fig. 9 - Evaluation of the created model significance at the considered beech sites by comparing measured and simulated beech increment indices over 1981-2010 period.

\section{Conclusions}

Frost in winter months and heat in June, along with drought in the growing period and more abundant precipitation in winter limited beech tree growth outside its natural distribution range in the north-eastern part of Europe. Higher concentration of surface ozone and sulphur deposition level

increased the negative effect on beech growth of the above key meteorological variables. Higher air concentrations of nitrate and their deposition level had a positive effect on beech growth. Based on the trends in air temperature and precipitation, probability of serious frost in winter and drought in summer should be reduced.

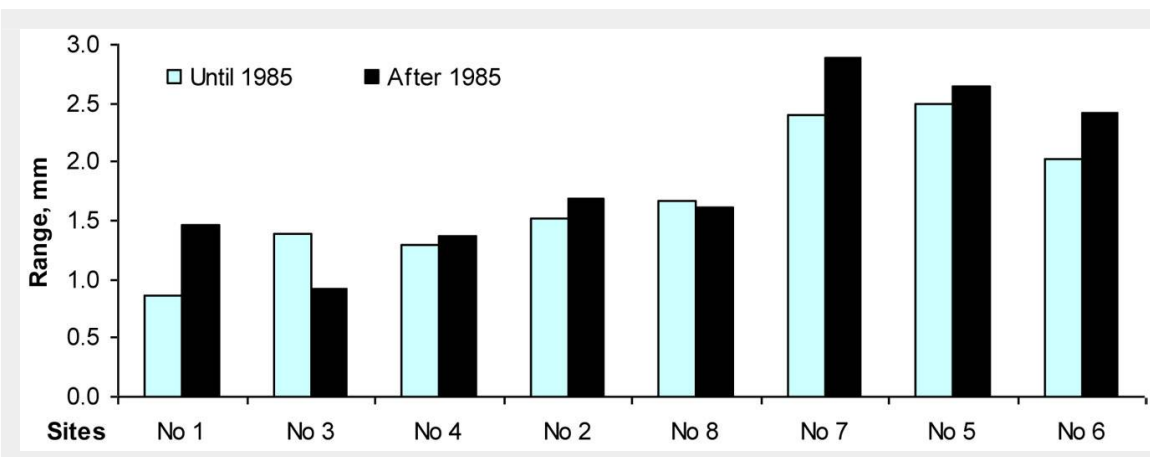

Fig. 10 - The range between maximal and minimal values of beech tree increment indices during 1950-1984 and 1985-2010. 
Cumulative precipitation over winter had a decreasing effect, reducing in turn the amount of acid deposition. Sulphur deposition until 2000 decreased more than tenfold and kept decreasing by approximately $10 \mathrm{mg} \mathrm{m}^{-2}$ per year up to $0.2-0.3 \mu \mathrm{g} \mathrm{S} \mathrm{m} \mathrm{m}^{-3}$ in 2011. Ozone also showed a tendency towards decreasing. Nitrate air concentration and its deposition over the last 20 years revealed a fertilizing effect on beech growth. Therefore, if changes in the above key parameters will persist, beech tree growth outside its distribution range should increase. The observed increase in the amplitude of variation of beech tree ring indexes may be interpreted as an indicator of the reduced resistance of beech trees to unfavorable environmental factors and possibly to their survival outside its natural range.

\section{References}

Aertsen W, Janssen E, Kint V, Bontemps JD, Van Orshoven J, Muys B (2014). Long-term growth changes of common beech (Fagus sylvatica L.) are less pronounced on highly productive sites. Forest Ecology and Management 312: 252-259. doi: 10.1016/j.foreco.2013.09.034

Augustaitis A, Juknys R, Kliučius A, Augustaitiene I (2003). The changes of Scots pine (Pinus sylvestris L.) tree stem and crown increment under decreased environmental pollution load. Ekologia Bratislava 22, Suppl. 1: 35-41. [online] URL: http://agris.fao.org/agris-search/search.do ?recordID=SK2003000363

Augustaitis A, Augustaitiene I, Cinga G, Mažeika J, Deltuvas R, Juknys R, Vitas A (2007). Did the ambient ozone affect stem increment of Scots pines (Pinus sylvestris L.) on territories under regional pollution load? Step III of Lithuanian studies. The Scientific World Journal 7: 58-66. doi: 10.1100/tsw.2007.55

Augustaitis A, Augustaitiene I, Kliučius A, Pivoras G, Šopauskiene D, Girgždiene R (2010a). The seasonal variability of air pollution effects on pine conditions under changing climates. European Journal of Forest Research 129: 431-441. doi: 10.1007/s10342-009-0319-x

Augustaitis A, Šopauskiene D, Baužiene I (2010b). Direct and indirect effects of regional air pollution on tree crown defoliation. Baltic Forestry 16: 23-34. [online] URL: http://www. balticforestry.mi.lt/bf/PDF_Articles/2010-16

[1]/BF1016123_24Augustaitisetal.pdf

Augustaitis A (2011). impact of meteorological parameters on responses of pine crown condition to acid deposition at Aukštaitija National Park. Baltic Forestry 17: 205-214. [online] URL: http://www.balticforestry.mi.lt/bf/PDF_Articles/ 2011-17[2]/Augustaitis_201117(2)_205_214.pdf

Augustaitis A, Jasineviciene D, Girgždiene R, Kliučius A, Marozas V (2012). Sensitivity of beech trees to global environmental changes at most north-eastern latitude of their occurrence in Europe. The Scientific World Journal 2012: 1-12. doi: 10.1100/2012/743926

Augustaitis A, Augustaitiene I, Mozgeris G, Juknys R, Vitas A, Jasinevičiene D (2014). Growth patterns of Scots pine (Pinus sylvestris L.) under the current regional pollution load in $\mathrm{Li}$ thuania. iForest. - doi: 10.3832/ifor1267-007
Baillie MGL, Pilcher JR (1973). A simple cross-dating program for tree-ring research. Tree-Ring Bulletin 33: 7-14.

Bolte A, Czajkowski T, Kompa T (2007). The north-eastern distribution range of European beech - a review. Forestry 4: 413-429. - doi: 10.1093/forestry/cpmo28

Bolte A, Hilbrig L, Grundmann B, Kampf F, Brunet J, Roloff A (2010). Climate change impacts on stand structure and competitive interactions in a southern Swedish spruce-beech forest. European Journal of Forest Research 129 (3): 261-276. - doi: 10.1007/s10342-009-0323-1 Bontemps JD, Hervé JC, Leban JM, Dhôte JF (2011). Nitrogen footprint in a longterm observation of forest growth over the twentieth century. Tree 25: 237-251. - doi: 10.1007/s00468-0100501-2

Braun S, Thomas VFD, Quiring R, Fluckiger W (2010). Does nitrogen deposition increase forest production? The role of phosphorus. Environmental Pollution 158: 2043-2052. - doi: 10.101 6/j.envpol.2009.11.030

Breda N, Huc R, Granier A, Dreyer E (2006). Temperate forests trees and stands under severe drought: a review of ecophysiological responses, adaptations processes and long-term consequences. Annals of Forest Science 63: 625644. - doi: 10.1051/forest:2006042

Comps B, Thiébaut B, Paule L, Merzeau D, Letouzey J (1990). Allozymic variability in beechwoods (Fagus sylvatica L.) over central Europe: spatial differentiation among and within populations. Heredity 65: 407-417. - doi: 10.1038/hdy. 1990.111

Cook ER (1987). The decomposition of tree ring series for environmental studies. Tree-Ring Bulletin 47: 37-59. [online] URL: http://hdl.handle. net/10150/261788

Cook ER, Kairiukštis LA (1990). Methods of dendrochronology. Kluwer, Dordrecht, The Netherlands, pp. 394.

Coomes DA, Allen RB (2007). Effects of size, competition and altitude on tree growth. Journal of Ecology 95:1084-1097. - doi: 10.1111/j.13652745.2007.01280.x

Cufar K, Prislan P, De Luis M, Gricar J (2008). Tree-ring variation, wood formation and phenology of beech (Fagus sylvatica L.) from a representative site in Slovenia, SE Central Europe. Trees 22 (6): 749-758. - doi: 10.1007/s00468008-0235-6

Dittmar C, Fricke W, Elling W (2006). Impact of late frost events on radial growth of common beech (Fagus sylvatica L.) in southern Germany. European Journal of Forest Research 125: 249259. - doi: 10.1007/s10342-005-0098-y

Dittmar C, Zech W, Elling W (2003). Growth variation of common beech (Fagus sylvatica L.) under different climatic and environmental conditions in Europe - a dendroecological study. Forest Ecology and Management 173 (1-3): 63-78. - doi: 10.1016/S0378-1127(01)00816-7

Draper NR, Smith H (1998). Applied regression analysis ( $3^{\text {rd }}$ edn). Wiley, New York, USA, pp. 736.

Dreimanis A (2004). Europäische Wurzeln der Forstwirtschaft in Lettland [European forestry roots in Latvia]. Der Wald 59: 514-515. [in German]

Eckstein D (1987). Measurement and dating pro- cedures in dendrochronology. In: "Methods of dendrochronology" (Kairiukštis L, Bednarz Z, Feliksik E eds). IIASA, Warsaw, Poland, vol. 3, pp. 35-44.

Eckstein D (1989). Qualitative assessment of past environmental changes. In: "Methods of dedrochronology. Applications in the environmental sciences" (Cook E, Kairiukštis L eds). Kluwer, Dordrecht, The Netherlands, pp. 220223.

European Environment Agency (2014). Elevation map of Europe. Web site. [online] URL: http:// www.eea.europa.eu/data-and-maps/data/digita l-elevation-model-of-europe

Ellenberg H (1996). Vegetation Mitteleuropas mit den Alpen in okologischer, dynamischer und historischer Sicht [Vegetation of Central Europe and the Alps in an ecological, dynamic and historical perspective]. Ulmer, Stuttgart, Germany, pp. 507. [in German]

EUFORGEN (2009). European forest genetic resources programme. International Plant Genetic Resources Institute (IPGRI) and the International Network for Improvement of Banana and Plantain (INIBAP). FAO, Rome, Italy, pp. 6. [online] URL: http://www.euforgen.org/filead min/bioversity/publications/pdfs/EUFORGEN/13 22_European_beech_Fagus_sylvatica_.pdf Girgzdiene R, Serafinaviciute B, Stakenas V, Bycenkiene $S$ (2009). Ambient ozone concentration and its impact on forest vegetation in Lithuania. AMBIO 38 (8): 432-436. - doi: 10.1579 / 0044-7447-38.8.432

Gradeckas A, Malinauskas A (2005). Biological and ecological fundamental research and experience on establishment of forest plantation in Lithuania. Lutute, Kaunas, Lithuania, pp. 404. [in Lithuanian]

Hanninen $\mathrm{H}$ (2006). Climate warming and the risk of frost damage to boreal forest trees: identification of critical ecophysiological traits. Tree Physiology 26: 889-898. - doi: 10.1093/ treephys/26.7.889

Holmes RL (1994). Dendrochronology program library. Laboratory of Tree-Ring Research, University of Arizona, Tucson, AZ, USA, pp. 52.

Jarcuška B (2009). Growth, survival, density, biomass partitioning and morphological adaptations of natural regeneration in Fagus sylvatica. A review. Dendrobiology 61: 3-11. [online] URL: http://www.cabdirect.org/abstracts/20113 401349.html

Juknys R, Augustaitis A, Vencloviene J, Kliučius A, Vitas A, Bartkevičius E, Jurkonis N (2014). Dynamic response of tree growth to changing environmental pollution. Journal of Forest Research 133: 713-724. - doi: 10.1007/s10342-013-07 $12-3$

Jump AS, Hunt JM, Penuelas J (2006). Rapid climate change-related growth decline at the southern range edge of Fagus sylvatica. Global Change Biology 12 (11): 2163-2174. - doi: 10.1111/ j.1365-2486.2006.01250.x

Klap JM, Oude Voshaar JH, De Vries W, Erisman JW (2000). Effects of environmental stress on forest crown condition in Europe. Part IV: Estimation of stress induced by meteorology and air pollutants. Water, Air and Soil Pollution 119: 387-420. - doi: 10.1023/A:1005157208701 Körner C (2007). The use of "altitude" in ecological research. Trends in Ecological Evaluation 22: 
569-574 - doi: 10.1016/j.tree.2007.09.006 Lebourgeois F, Bréda N, Ulrich E, Granier A (2005). Climate-tree-growth relationships of European beech (Fagus sylvatica L.) in the French Permanent Plot Network (RENECOFOR). Trees 19: 385-401. - doi: 10.1007/s00468004-0397-9

Marozas V, Augustaitis A, Armolaitis K, Kliučius A, Pilkauskas M (2014). Effects of planted European beech on the understory in Scots pine forests of Lithuania. iForest - Biogeosciences and Forestry 7: 12-18. - doi: 10.3832/iforo695-007 Matyssek R, Innes JL (1999). Ozone - a risk factor for trees and forests in Europe? Water, Air and Soil Pollution 116: 199-226. - doi: 10.1023/A: 1005267214560

Matyssek R, Bahnweg G, Ceulemans R, Fabian P, Grill D, Hanke DE, Kraigher H, Osswald W, Rennenberg $H$, Sandermann $H$, Tausz $M$, Wieser $G$ (2007). Synopsis of the CASIROZ case study: carbon sink strength of Fagus sylvatica $L$. in a changing environment - experimental risk assessment of mitigation by chronic ozone impact. Plant Biology 9: 163-180. - doi: 10.1055/s-20 07-964883

Matyssek R, Wieser G, Ceulemans R, Rennenberg $\mathrm{H}$, Pretzsch $\mathrm{H}$, Haberer K, Löw M, Nunn AJ, Werner H, Wipfler P, Oßwald W, Nikolova P, Hanke DE, Kraigher $\mathrm{H}$, Tausz M, Bahnweg G, Kitao M, Dieler J, Sandermann H, Herbinger K, Grebenc T, Blumenröther $M$, Deckmyn $G$, Grams TEE, Heerdt C, Leuchner M, Fabian P, Häberle KH (2010). Enhanced ozone strongly reduces carbon sink strength of adult beech (Fagus sylvatica L.) - Resume from the free-air fumigation study at Kranzberg Forest. Environmental Pollution 158: 2527-2532. - doi: 10.1016/j. envpol.2010.05.009

Maxime C, Hendrik D (2011). Effects of climate on diameter growth of co-occurring Fagus sylvatica and Abies alba along an altitudinal gradient. Trees 25: 265-276. - doi: 10.1007/s00468010-0503-0

Mayer H (1984). Waldbau auf soziologisch-okologischer Grundlage, 3Aufl [Silviculture based on social-ecological basis]. Fischer, Stuttgart, Germany, pp. 63-91. [in German]

McLaughlin SB, Shortle WC, Smith KT (2002). Dendroecological applications in air pollution and environmental chemistry: research needs. Dendrochronologia 20 (1-2): 133-157. - doi: 10.10 78/1125-7865-00013

Mund M, Kutsch W, Wirth C, Kahl T, Knohl A, Skomarkova M, Schulze E-D (2010). The influence of climate and fructification on the inter- annual variability of stem growth and net primary productivity in an old-growth, mixed beech forest. Tree Physiology 30: 689-704. doi: 10.1093/treephys/tpq027

Paoletti E, Schaub M, Matyssek R, Wieser G, Augustaitis A, Bastrup-Birk AM, Bytnerowicz A, Günthardt-Goergb MS, Müller-Starck G, Serengil $Y$ (2010). Advances of air pollution science: from forest decline to multiple-stress effects on forest ecosystem services. Environmental Pollution 158: 1986-1989. - doi: 10.1016/j.envpol. 2009.11.023

Pilkauskas M, Augustaitis A, Marozas V (2011). Growth peculiarities of European beech trees outside their natural distribution range in Lithuania. In: Proceedings of the $5^{\text {th }}$ International Scientific Conference "Rural development 2011". Akademija, Kaunas (Lithuania) 2425 Nov 2011, vol. 5, pp. 106-110.

Pretzsch H, Dieler J, Matyssek R, Wipfler P (2010). Tree and stand growth of mature Norway spruce and European beech under longterm ozone fumigation. Environmental Pollution 158: 1061-1070. - doi: 10.1016/j.envpol.2009. 07.035

Scalfi M, Troggio M, Piovani P, Leonardi S, Magnaschi G, Vendramin GG, Menozzi P (2004). A RAPD, AFLP and SSR linkage map, and QTL analysis in European beech (Fagus sylvatica L.). Theoretical ans Applied Genetics 108: 433-441. doi: 10.1007/s00122-003-1461-3

Scharnweber T, Manthey M, Criegee C, Bauwe A, Schröder C, Wilmking M (2011). Drought matters - declining precipitation influences growth of Fagus sylvatica L. and Quercus robur L. in north-eastern Germany. Forest Ecology and Management 262: 947-961. - doi: 10.1016/j.for ec0.2011.05.026

Schweingruber FH (1996). Tree rings and environment: dendroecology. Paul Haupt Publishers, Bern, Switzerland, pp. 609. [online] URL: http://www.cabdirect.org/abstracts/199806024 76.html

Serengil Y, Augustaitis A, Bytnerowicz A, Grulke N, Kozovitz AR, Matyssek R, Müller-Starck G, Schaub M, Wieser G, Coskun AA, Paoletti E (2011). Adaptation of forest ecosystems to air pollution and climate change. iForest - Biogeosciences and Forestry 4: 44-48. - doi: 10.3832/ iforo566-004

Solberg S, Dobbertin $M$, Reinds $G J$, Lange $H$, Andreassen K, Fernandez PG, Hildingsson A, De Vries W (2009). Analyses of the impact of changes in atmospheric deposition and climate on forest growth in European monitoring plots: a stand growth approach. Forest Ecology and Management 258: 1735-1750. - doi: 10.1016/j.for eco.2008.09.057

Sopauskiene D, Jasineviciene D (2006). Changes in precipitation chemistry in Lithuania for 19812004. Journal of Environmental Monitoring 8: 347-352. - doi: 10.1039/B516877E

Tarp P, Helles F, Holten-Andersen P, Larsen JB, Strange N (2000). Modelling near-natural silvicultural regimes for beech - an economic sensitivity analysis. Forest Ecology and Management 130 (1-3): 187-198. - doi: 10.1016/S0378-1127(99) 00190-5

Tegel W, Seim A, Hakelberg D, Hoffmann S, Panev M, Westphal T, Büntgen U (2014). A recent growth increase of European beech (Fagus sylvatica L.) at its Mediterranean distribution limit contradicts drought stress. European Journal of Forest Research 133: 61-71. doi: 10.1007/s10342-013-0737-7

Teissier du Cros E, Le Tacon F, Nepveu G, Pard J, Perrin R, Timbal J (1981). Le Hetre. INRA, Department des Reserches Forestieres, Paris, France, pp. 35-46.

Thomas VFD, Hiltbrunner E, Braun S, Flückiger W (2002). Changes in root starch contents of mature beech (Fagus sylvatica L.) along an ozone and nitrogen gradient in Switzerland. Phyton 42: 223-228. [online] URL: http://www. engineeronline.net/wp-content/uploads/2015/

Thomas VFD, Braun S, Flückiger W (2006). Effects of simultaneous ozone exposure and nitrogen loads on carbohydrate concentrations, biomass, growth, and nutrient concentrations of young beech trees (Fagus sylvatica L.). Environmental Pollution 143: 341-354. - doi: 10.1016/j.envpol.2005.11.036

UN-ECE (2013). The condition of forests in Europe. Executive Report 2013, EN-ECE CLRTAP\&ICP Forest with EC European Directorate General LIFE Unit, Germany, pp. 28. [online] URL: http:// icp-forests.net/page/icp-forests-executive-repo rt

UNEP (2004). 2003 heat wave in Europe (De Bono A, Peduzzi P, Kluser S, Giuliani G eds). UNEP, Environment Alert Bulletin 2: 4. [online] URL: http://www.grid.unep.ch/products/3_Re ports/ew_heat_wave.en.pdf

Zweifel R, Zimmermann L, Zeugin F, Newbery DM (2006). Intra-annual radial growth and water relations of trees: implications towards a growth mechanism. Journal of Experimental Botany 57:1 445-1459. - doi: 10.1093/jxb/erj125 